\title{
Communications
}

2015; 3(5): 146-149

Published online August 27, 2015 (http://www.sciencepublishinggroup.com/j/com)

doi: 10.11648/j.com.20150305.20

ISSN: 2328-5966 (Print); ISSN: 2328-5923 (Online)

\section{College English Teachers' “Content-Based” Professional Development in China}

\author{
Wenmin $\mathrm{Li}^{1}$, Shihan $\mathrm{Hou}^{2}$, Juxia Zhai ${ }^{1}$ \\ ${ }^{1}$ Culture and Communication School, Shaanxi University of Science and Technology, Xi'an, China \\ ${ }^{2}$ Foreign Languages Department, Haojing College of Shaanxi University of Science and Technology, Xi'an, China
}

Email address:

yezi_wm66@163.com (Wenmin Li)

\section{To cite this article:}

Wenmin Li, Shihan Hou, Juxia Zhai. College English Teachers' "Content-Based” Professional Development in China. Communications. Vol. 3, No. 5, 2015, pp. 146-149. doi: 10.11648/j.com.20150305.20

\begin{abstract}
This paper mainly discusses the necessity of, and the way to college English teachers' content-based professional development in China, one of the main conclusions drawn from the case study of a provincial education department-funded project (see footnote). It draws on the pilot project on college English teaching reform which, with action research employed, aims to figure out the problems exposed to college English teaching and looks to put forward effective ways of college English teachers' professional development fitted into Chinese educational and economic globalization.
\end{abstract}

Keywords: Content-Based, Professional Development, College English, Participant Action Research, Experimental Action Research, Globalization

\section{Introduction}

English is believed to be the global lingua franca of the modern era in many aspects such as international business, computer science, mass media and the international conferences. It is spoken and studied by more and more people of different nations, among whom, nonnative English speakers are estimated to far more outnumber native-English speakers. Native and nonnative speakers combined, English is the most widely spoken language worldwide.[ McCrum, Robert; MacNeil, Robert; Cran, William (2003)][ (2003a)] As for the English teachers worldwide, "about $80 \%$ of them worldwide are nonnative speakers of the language." [Braine, (2010), p. x] So, what's then? Are the nonnative-English speaker teachers well qualified for teaching English with the globalization of economy and its effect on education ? How could they improve their professional development facing the challenge of the native-English speaker teachers, and that of the globalization of the world economy?

English, though a foreign language, functions increasingly important in today's China which is a member of United Nations, of the U.N. Security Council and of numerous world organizations such as the WTO, APEC, and the Shanghai Cooperation Organization. China ranking $1^{\text {st }}$ in its world's trading with a total international trade value of US\$3.87 trillion in 2012,[ White, Garry (2013)] and Chinese higher education opening up to the outside world with more communication, more and more Chinese people consider mastery of English a must and regard it as a utility and essential tool to keep pace with the globalization of the world economy. There are many ways to learn English in the context of China's all-round opening up policy. College English, the first two-year required course, is open to all non-English undergraduates at almost all the universities in China. No wonder it is a great challenge Chinese college English teachers may encounter in their teaching career.

Research on "content-based" college English teaching, taking college English teaching reform in Shaanxi University of Science and Technology as a case study, is a pilot project funded by education department of Shaanxi Provincial Government in Shaanxi Province, China. Shaanxi University of Science and Technology, as it is called, is mainly a school of science and technology which outstands in technology of light industry such as leather technology and paper making technology. College English teaching reform experiment started in September, 2013 in Shaanxi University of Science and Technology, According to the related set of disciplines of the non-English undergraduates whom college English teachers teach, college English teachers were rearranged into 4 teaching teams: of light industry, of electronics, of engineering and of arts. Team of arts, consisting of 16 teachers and responsible for about 2400 students of arts in two grades from three colleges concerning business, art of design and 
mass media, put forward their idea of teaching reform experiment and were given the priority from its college, thus having the chance to put the idea into practice. Meanwhile, they applied for a content-based teaching reform program from Shaanxi province and succeeded in it. That is the pilot project. It's coming to an end for the first round of experiment from September 2013 to July 2015 with a total plan of 2 rounds. Some notable changes were made during the experimental teaching reform. College English course was divided into three independent courses: one is listening and speaking, another two are reading and writing; Teachers are divided into two groups: one group consisting of 4 native-English speaker teachers, and 4 Chinese English teachers are responsible for listening and speaking. The other one consists of 8 Chinese English teachers taking two courses reading and writing each person; English for special purpose (ESP) as course of reading and writing meets non-English sophomores in their second year English classes; Native-English speaker teachers were first invited to course of college English at least in Xi' an, western part of China. That is to say, students of arts can meet 2 English teachers with 2 courses each term, and some of them can have a native-English speaker teacher in their class of listening and speaking. While traditionally non-English students meet only one English teacher with only one course for college English each term and they never have native- English speaker teacher in class. And general English is the only way in college English class. With action research employed during the teaching reform, the pilot project means to figure out problems existing in college English teaching and looks to put forward effective ways of college English teachers' professional development fitted into Chinese educational and economic globalization. Some problems have been exposed to college English teaching through action research on the teaching reform experiment in the first round. It's suffice to put main focus on college English teachers' professional development in this paper together with only a brief introduction of action research employed. Other conclusions or problems found in the pilot project and action research concerned will be discussed in series in my later papers.

\section{Action Research}

Action research might be described as an inquiry conducted into a particular issue of current concern, usually undertaken by those directly involved with the aim of implementing a change in a specific situation. [Hitchcock \& Hughes, (1989:7)] This theory was thought to be originated by Lewin on his research in "natural settings" in 1930s. He did a lot of research in which he created action research and in turn employed it as theoretical guide. This can be seen in his works such as (1920) Die Sozialisierung des Taylorsystems, Praktischer Sozialismus, No. 4; (1939) Patterns of aggressive behaviour in experimentally created social climates, Journal of Social Psychology, 10, (Lewin, K., Lippett, R. \& White, R.K.); (1946) Action research and minority problems, in G.W.; (1948) Resolving Social Conflicts. New York: Harper \& Row. pp.
271-301 and (1947) Frontiers in Group Dynamics, Concept, Method and Reality in Social Science; Social Equilibria and social Change. Lewin classified his work into four types of action research: 1). Diagnostic action research: It is designed to produce a needed plan of action. The change agents would intervene in an already existing situation (for example, a race riot or anti-Semitic vandalism), diagnose the problem, and recommend remedial measures. Unless the proposed cures were feasible, effective, and acceptable to the people involved, however, this design of action was often wasted. 2). Participant action research: it is assumed that the residents of the affected community who were to help effect a cure must be involved in the research process from the beginning. 3). Empirical action research: It was primarily a matter of record keeping and accumulating experiences in day-to-day work, ideally with a succession of similar groups, such as boys' clubs. 4). Experimental action research: It called for a controlled study of the relative effectiveness of various techniques in nearly identical social situations. [Clem Adelman (1993)]

We employed participant action research and experimental action research in the above mentioned project concerning experiment of college English teaching reform in Shaanxi University of Science and Technology. All the teachers in team of arts are involved in college English teaching reform in which 2013 class of students of arts was chosen to lead the experiment in September, 2013. 2014 class of students of arts followed next with something new changed in September, 2014. This is the major change made for experiment after one year's action research. Only 4 classes of about 120 students with about 30 in each class (single fixed class in Chinese universities), instead of about 70 students (combined classes for purpose of some general education including English and Maths) are chosen for experiment in listening and speaking with 2 foreign English teachers and 2 Chinese English teachers. The above four English teachers take lectures both for single-class students and the combined-class students so as to make good comparison and draw new conclusion through action research the teacher participants are doing. While 2013 class of students of arts began course of ESP as reading and writing at their second year college English study in which History of Western Art was chosen for students from College of art \& design and Culture and Communication School, and Business English for students from college of Trade of Business as their text books. ESP course was brand new and a great challenge to both teachers and students, for the teachers had never taught it before and the students were blind to the ESP-related expertise before their third year. Among the teachers of reading and writing responsible for 2013 class of students, two of them gave lectures with History of Western Art (in English) and the other two with Business English (in English). Every two cooperated to make the teaching plan fit for the target students and do some research on the related discipline to make fully self-prepared before class. Two of the authors in this paper, Wenmin Li and Juxia Zhai are among the teachers giving lectures for ESP course separately with History of Western Art and Business English. This is learning and improving by doing and what's more, it's part of teaching 
reform as well as participant and experimental action research in the pilot project. Some conclusions are drawn out of one year's practice of ESP course through questionnaires: ESP is found more interesting and functional than general English; Textbook History of Western Art is much too high beyond the level of the students though functional, for most of the students majoring in art and in mass media are weaker in English than those from other majors; the most serious deficiency to college English teachers facing the new challenge of college English teaching reform, as we ourselves described by questionnaire, is badly short of content-based knowledge, hard to learn but essential to have and fatal without in the context of world economic and educational globalization. It's urgent for both us college English teachers and the national educational government to realize the importance and necessity of college English teachers' "content-based" professional development.

\section{Dilemma of College English Teachers in China}

There are over 100000 college English teachers in China, most of whom graduated in English language and literature from English Department of colleges or universities, instead of that of normal colleges or normal universities. They are found to be in a dilemma neither familiar with pedagogy nor expertise of the related majors in the context of the world economic and educational globalization. More and more native-English speaker teachers choose to teach English both in middle schools and universities in China. Undeniably most of Chinese college English teachers will fail their competition in both speaking and the related English - speaking countries' culture when facing native-English speaker teachers who were not English majors when in colleges. They are also facing a challenge of self- improvement in English language proficiency, when working together with native-English speaker teachers. At the same time, college English teachers will feel embarrassed when facing teachers of bilingual subject matter from college of the related discipline, whose expertise outstands, oral English sounds a bit more awkward, though.

With the rapid economic development and the world globalization, China is believed to become more and more communicative and open to the outside world. English is accessible to Chinese people through many ways including traveling abroad, reading and watching in newspaper, on TV or internet. More and more people know English better than ever before. Meanwhile, reform on English exam for college entrance in China which can be taken for twice a year and reform on college English Band 4 have great influence on college English. Besides, more and more students have chance to go abroad as exchange students in their middle school or at college, exposed themselves to the English language environment for a period of time. General English is no longer omnipotent as it was in today's college and college English teachers will no longer stay in permanent position if they refuse to change themselves. They are facing a challenge of self-improvement in ESP based knowledge, being teachers responsible for the related discipline.

\section{Chinese College English Teachers' "Content-Based" Professional Development}

The term "content-based" actually originated from the mid-1970s French immersion program experimented among the English speaking population of Canadian province of Quebec, in which French (official language of Quebec) was employed as the medium of instruction of the school curriculum. [Swain \& Johnson, (1997)] Content here means the concrete school curriculum, and language the medium or form. Both form and functional content are significantly inseparable in language learning. [Met, (1991); Lightbown \& Spada, (1993)] The immersion program there not only witnessed the great success for learners to simultaneously acquire subject matter expertise and greater proficiency in French, the second Language in Quebec,[ D. Raphan \& J. Moser: (1994) ] but revealed its importance and value economically, politically, socially and culturally. [Swain \& Johnson, (1997)]

The term "content-based" was widely used in research on English learning in China. The requirement for college English teachers" "content-based" professional development varies depending on the economic, social, and educational context college English teachers are in. Simple general English as college English was taught in universities of China in the 1980s when China began to open its door to the outside world. Few Chinese people knew English then. The purpose of college English is to popularize basic knowledge of English language. It was sufficient for college English teachers to well qualify themselves as English teachers with English grammar and vocabulary and certain level of reading capacity after they graduated from English department of colleges or universities. "Content" here refers to grammar, vocabulary, and reading capacity of English. While the economic, social, and educational context has made it changed greatly now. What would the basic required college English do to strengthen the students if they wanted to work in the international organizations or businesses after their graduation or if they had chance to attend an international conference concerning their specialties, which means request for papers in English or even for presentation at conference in English? Are college English teachers able to help those who are their students in English class in these cases? Brinton et al believes that "the language syllabus must take into account the uses the learner will make of the target language", [Brinton et al (1989)] which draws more attention to the content best serving the students functionally in their future career.

With the world economic globalization, the economic, scientific and educational development of China, it's more likely for college students to employ English in their future work. So Chinese college English teachers' "content-based" professional development should shed light on "subject 
matter-based" knowledge and proficiency of English language so as to be competent in making proper integration of English language skills and subject matter in college English teaching, thus achieve the final objective in college English teaching: assess subject matter and language skills within the educational system and enhance the development of intellectual skills.[ NAVES' GRID, website]

There are several effective ways for Chinese college English teachers to improve "content-based" professional development in the context of globalization. Apply for visiting scholarship abroad to native-English speaking countries for higher level of English proficiency, immersing oneself in English environment, meanwhile choose one discipline-based curriculum one is interested in such as business communication or art communication when you are abroad; Organize team of research with invitation of one or two native-English speaker teachers and one bilingual teacher from college of the related discipline so that they can do research together, sharing opinion and learning by doing; choose some experienced and outstanding college English teachers as advisors. Each of the advisors is requested to take responsibility for 4 comparatively inexperienced young teachers. They can audit the advisor's lectures and learn how college English lectures can be efficient and functional. Of course the advisor has the duty to audit his or her "apprentice"s' lessons and share what he or she thinks with them then. The world offers us many other resources with which we can make full use of to implement self improvement.

\section{Summary}

College English has existed for more than 30 years in China and college English teachers had exerted great influence in China's higher education in the past, which doesn't imply that we Chinese college English teachers can ignore the challenges we are facing today. What does major of English mean when English becomes nothing but a tool? What do college English teachers mean if college English is taught with nothing functional but grammar, vocabulary and sentence making?

Take actions to activate college English. Just keep it in memory that both college English and its teachers in China will be eliminated if no functional changes show up.

\section{Funding}

This paper is funded by pilot project of education Department of Shaanxi Provincial Government named
Research on "Content-based" College English Teaching Reform-A Case Study of College English Teaching Reform Experiment in Shaanxi University of Science and Technology (13BY42)

\section{References}

[1] Braine, G. ( 2010 ). Nonnative Speaker English Teachers: Research, Pedagogy and Profes- sional Growth. New York : Routledge.

[2] McCrum, Robert; MacNeil, Robert; Cran, William (2003). The Story of English(Third Revised ed.). London: Penguin Books. ISBN 978-0-14-200231-5.

[3] Crystal, David (2003a). English as a Global Language (2nd ed.) Cambridge University Press. p. 6. ISBN 978-0-521-53032-3. Retrieved 4 February 2015. Lay summary (PDF) - Library of Congress (sample) (4 February 2015). The statistics collected in chapter 2 suggest that about a quarter of the world's population is already fluent or competent in English, and this figure is steadily growing - in the early 2000 s that means around 1.5 billion people.

[4] White, Garry (10 February 2013). "China trade now bigger than US". Daily Telegraph (London). Retrieved 15 February 2013.

[5] Hitchcock, G. and Hughes, D.( 1989) Research and the Teacher London: Routledge.

[6] Clem Adelman (1993) Kurt Lewin and the Origins of Action Research, Educational Action Research, DOI: 10.1080/0965079930010102, London: Routledge

[7] Swain, M. \& Johnson, R.K. (1997). Immersion education: A category within bilingual education. In R. K. Johnson \& M. Swain (Eds.)Immersion Education: International Perspectives (pp. 1-16). NY: Cambridge University Press.

[8] Raphan, D. and Moser, J. (1993/1994, Winter). Linking language and content: ESL and art history. TESOL Journal, $17-21$.

[9] Met, M. (1991). Learning language through content: Learning content through language. Foreign Language Annals, 24(4), 281-295.

[10] Lightbown, P. M. \& Spada, N. (1993). How languages are learned. NY: Oxford University Press.

[11] NAVES' GRID, CONTENT-BASED INSTRUCTION (USA) CLIC (Content and Language Integrated Classroom ) (Europe). Website. 